\title{
Low Pressure Carbonylation of Benzyl Chloride
}

\section{Die Carbonylierung von Benzylchlorid bei niedrigen Drücken}

\author{
H. J. LUGGENHORST and K. R. WESTERTERP \\ Chemical Reaction Engineering Laboratories, Department of Chemical Engineering, Twente \\ University of Technology, P.O. Box 217, 7500 AE Enschede (The Netherlands) \\ (Received October 7, 1985)
}

\begin{abstract}
For carbonylations, metal carbonyls, particularly cobalt and iron carbonyls, are often used as catalysts. These reactions take place under rather drastic reaction conditions, e.g. $200-300{ }^{\circ} \mathrm{C}$ and $60-100 \mathrm{MPa}$. In some patents it is stated that similar reactions using the same catalysts can also be carried out under rather mild reaction conditions, such as $0-100^{\circ} \mathrm{C}$ and $0-2.5 \mathrm{MPa}$.

We studied the conversion of benzyl chloride to phenyl acetic methyl ester in a semi-batch reactor in which one of the reactants was slowly added to the reactor. In this way a non-catalysed parallel reaction could be oppressed for the greater part.

The highest conversions and selectivities were obtained when a solution of sodium methylate in methanol was slowly added to a reaction mixture containing benzyl chloride. In this way under optimized conditions a conversion of benzyl chloride of $100 \%$ has been found.

It also appears that the conversion and selectivity decrease not only at low but also at high CO partial pressures. A possible explanation for this phenomenon will be given.
\end{abstract}

\section{Kurzfassung}

Bei Carbonylierungsreaktionen werden oft Metallcarbonyle, insbesondere Kobalt- und Eisencarbonyl als Katalysatoren benutzt. Diese Reaktionen werden unter ziemlich drastischen Bedingungen (z.B. bei 200-300 ${ }^{\circ} \mathrm{C}$ und $60-100 \mathrm{MPa}$ ) durchgeführt. In der Patentliteratur sind Beschreibungen von ähnlichen Reaktionen zu finden, die bei der Anwendung derselben Katalysatoren unter viel milderen Bedingungen (wie z.B. $0-100^{\circ} \mathrm{C}$ und $0,1-2,5 \mathrm{MPa}$ ) durchgeführt werden können.

Wir untersuchten die Umsetzung von Benzylchlorid zum Phenylacetmethylester in einem 'semi-batch'-Reaktor wobei einer der Reaktanten langsam dem Reaktor zugeführt wurde. Auf diese Weise konnte eine unerwünschte, nichtkatalytische Nebenreaktion in wesentlichem Ausmass unterdrückt werden.

Die höchsten Umsetzungsgrade und Selektivitäten wurden erreicht mit einer langsamen Dosierung einer Lösung von Natriummethylat im Methanol zur Benzylchlorid-Phase. Nach einer Optimierung der Prozessbedingungen wurde eine $100 \%$-ige Umsetzung der Benzylchlorids erreicht.

Eine Abnahme des Umsetzungsgrades und der Selektivität wurde nicht nur bei niedrigen, sondern auch bei hohen Partialdrücken des Kohlenmonoxydes festgestellt. Eine mögliche Erklärung dieses Phänomens wird vorgeschlagen.

\section{Synopse}

Es ist nicht deutlich, warum man in der Industrie die Carbonylierungsreaktionen unter sehr drastischen Bedingungen $\left(200-300^{\circ} \mathrm{C}, 60-100 \mathrm{MPa}\right)$ durchführt, während sie bereits unter viel milderen Reaktionsbedingungen $\left(0-100{ }^{\circ} \mathrm{C}\right.$ und $\left.0,1-2,5 \mathrm{MPa}\right)$ mit denselben Katalysatoren verlaufen können. Aus den Patenten der Dynamit Nobel A.G. [5-8] scheint der Dikobaltoctacarbonyl der beste Katalysator für milde Reaktionsbedingungen zu sein. Im allgemeinen sind in der Patentliteratur mehrere Beispiele der Niederdruck-Carbonylie- rungsreaktionen zu finden, es fehlen jedoch Daten über den Einfluss der Temperatur und des CO-Partialdruckes auf den Konversionsgrad und auf die Selektivität.

Die Synthese des Phenylessigsäure-Methylesters ist eine der Carbonylienungsreaktionen, die unter milden Bedingungen verläuft. Ein mögliches Reaktionsschema ist mit Gl. (I)-(III) dargestellt. Die Bildung des Methylbenzyläthers $(G l$. (IV)) ist die wichtigste Nebenreaktion. Alle Experimente wurden in der auf $A b b .1$ vorgestellten Apparatur durchgeführt. Um Korrosion der Autoklavwand $z u$ verhindern $[22,23]$ wurde ein Innengefäss aus Glas benützt, wodurch die Kontrolle der Reaktor- 
temperatur schwierig war: es gab Temperatursteigerungen von $15-30^{\circ} \mathrm{C}$. Deswegen sind auch in der Tabelle 1 mit den Messergebnissen mittlere Temperaturen angegeben. Nach jedem Experiment wurde der Reaktorinhalt chromatographisch analysiert. Dazu wurde eine 2 Meter lange $1 / 4^{\prime \prime}$ Glaskolonne benutzt, gefüllt mit Chromosorb W-HP (80/100 mesh) mit 5\% FFAP. Auf Grund der Gl. (1) und (2) konnten die Ergebnisse der Analyse in den Konversionsgrad und die Selektivität umgerechnet werden. Die zwei folgenden Versuchsmethoden wurden angewandt:

(1) eine langsame Zuführung von Benzylchlorid in eine Lösung des Natriummethylats und des Katalysators im Methanol und

(2) eine langsame Zuführung einer Natriummethylatlösung in eine Mischung von Benzylchlorid, Katalysator und Methanol.

Die Resultaten sind in Tab. 1 sowie auf Abb. 2-6 gegeben. Auf Abb. 2 ist der Einfluss des CO-Purtialdruckes ( $A b b$. 2(a)) und der Temperatur ( $A b b$. 2(b)) auf den Konversionsgrad (unterer Teil des Diagrammes) und auf die Selektivität (oberer Teil) für die Experimente wiedergegeben, bei denen Benzylchlorid einer Lösung des Natriummethylats und des Dikobalt-octakarbonyl im Methanol langsam zugeführt wurde.

Abbildungen 3-5 entsprechen den Experimenten, bei denen cine Natriummethylatlösung langsam in eine Mischung von Benzylchlorid, Dikobalt-octakarbonyl und Methanol dosiert wurde. Auf Abb. 3(a) ist der Einfluss des CO-Partialdruckes auf den Konversionsgrad und auf die Selektivität gezeigt. Auffallend ist hierbei die Abnahme des Konversionsgrades bei CO-Partialdnücken ab 0,85 MPa. Den zwei möglichen Erklärungen dieses Phänomens liegen die Reaktionen $\mathrm{Gl}$. (V) und (VI) zugninde. Bei Reaktion (VI) geht man davon aus, dass der bei hohen CO-Partialdruck entstehende Kobaltkomplex durch den Natriummethylat nicht ersetzt werden kann; der Katalysator wird also umgesetzt in eine inaktive Komplexverbindung. Es ist schwierig, sich für eines der Modelle zu entscheiden.

Die erste Erklänung, die der $G$. (V) entspricht, scheint uns plousibler zu sein.

Der Konversionsgrad und die Selektivität werden auch durch die Geschwindigkeit der Dosierung von Natriummethylat beeinflusst (Abb. 4(a)). Bei einer langsamen Dosierung wird eine langsame und konstante Deaktivienung des Katalysators beobachtet, während bei einer schnellen Dosierung der Deaktivienungsprozess wegen der limitierten Zuführung von $\mathrm{CO}$ und der hohen Konzentration des Natriummethylats beschleunigt wird. $A b b$. 5 stellt bei verschiedenen Dosienungsgeschwindigkeiten den $\mathrm{CO}$-Verbrauch während der Zuführung der ersten $80 \%$ des Natriummethylats dar. Bei der Dosienungskapazität von $0,360-10^{-3} \mathrm{~mol} \mathrm{~mol}^{-1} \mathrm{~s}^{-1}$ oder höher limitiert der CO-Transport aus der Gasphase in die flüssige Phase den CO-Verbrauch. Auf Abb. 4(b) zeigt sich, dass sowohl der Konversionsgrad als auch die Selektivität durch die Drehzahl des Rührers beeinflusst werden: bei niedrigen Drehzahlen wird die Reaktionsgeschwindigkeit durch die Stoffubertragung limitiert.

$A u f$ Abb. 6 ist der CO-Verbrauch, der ein direkter Mass der Kapazität ist, als Funktion der Verweilzeit dargestellt. Abbildung $6(a)$ entspricht einer langsamen Dosierung von Benzylchlorid. Bei langsamer Dosienung von Natriummethylat (Abb. 6(b)) bleibt am Anfang des Experiments der $\mathrm{CO}$-Verbrauch auf einem konstanten Niveau.

\section{Introduction}

Carbonylation processes are widely used in industry. Originally only olefines were carbonylated [1], but nowadays so are alkyl halides, aromatic halides, esters and ethers [2-4]. These reactions are carried out under rather drastic reaction conditions such as at temperatures of $200-300{ }^{\circ} \mathrm{C}$ and $\mathrm{CO}$ partial pressures of $60-100 \mathrm{MPa}$. The catalysts used are normally nickel, iron or cobalt carbonyls. By applying the more active rhodium and palladium catalysts like $\mathrm{RhCl}(\mathrm{CO})\left[\left(\mathrm{C}_{5} \mathrm{I}_{6}\right)_{3} \mathrm{P}\right]_{2}$ or $\operatorname{Pd}\left[\left(\mathrm{C}_{5} \mathrm{H}_{6}\right)_{3} \mathrm{P}_{2} \mathrm{Cl}_{2}\right.$ the carbonylation process can be carried out under less severe conditions, e.g. at $100{ }^{\circ} \mathrm{C}$ and $\mathrm{CO}$ partial pressures of $2.5-10 \mathrm{MPa}$. From recent patents $[5-8]$ it is known that similar reactions can also be carried out under milder reaction conditions $\left(0-100{ }^{\circ} \mathrm{C}\right.$ and $\left.0-2.5 \mathrm{MPa}\right)$, whereas cobalt carbonyl is used as catalyst. It is not clear why in industry rather severe conditions are applied when the same catalyst also works well under mild conditions: such conditions, together with the use of the relatively cheap cobalt carbonyl as a catalyst, make carbonylation a very attractive route for the synthesis of fine chemicals. At low pressures the invesiment costs are sufficiently reduced to become economically attractive for the manufacture of low volume chemicals. By carbonylation it is possible to make esters, acids and amides directly from chlorides.

In patents [5-8] Dynamit Nobel A.G. gives some examples of low pressure carbonylations. In the first patent on this subject [5] several cobalt salts, some with special additives, are used as catalysts. Dicobalt octacarbonyl turns out to be the best catalyst. In the patents a great number of concrete examples of low pressure carbonylations are given. We could not find further information on the influence of temperature and $\mathrm{CO}$ partial pressure on the conversion or the selectivity of carbonylations under mild conditions.

One of the many possibilities is the synthesis of phenyl acetic methyl ester. The route used for synthesis at present employs hydrogen cyanide [9]. The potassium or sodium salt of phenyl acetic acid is a raw material for the synthesis of penicillin. A possible reaction scheme for the carbonylation of benzyl chloride to phenyl acetic methyl ester is the following:

$$
\begin{aligned}
& \mathrm{R}-\mathrm{Cl}+\mathrm{Co}(\mathrm{CO})_{4}{ }^{-} \longrightarrow \mathrm{R}-\mathrm{Co}(\mathrm{CO})_{4}+\mathrm{Cl}^{-} \\
& \mathrm{R}-\mathrm{Co}(\mathrm{CO})_{4}+\mathrm{CO} \longrightarrow \mathrm{R}-\stackrel{\mathrm{O}}{\mathrm{C}}-\mathrm{Co}(\mathrm{CO})_{4}
\end{aligned}
$$

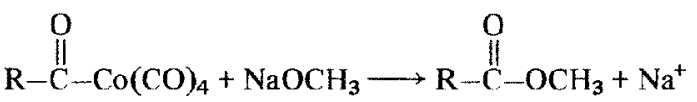

$$
\begin{aligned}
& +\mathrm{Co}(\mathrm{CO})_{4}^{--}
\end{aligned}
$$

with $\mathrm{R}-=\mathrm{C}_{6} \mathrm{H}_{5}-\mathrm{CH}_{2}-$. 
The most important side reaction is the non-catalysed formation of methyl benzyl ether:

$\mathrm{R}-\mathrm{Cl}+\mathrm{NaOCH}_{3} \longrightarrow \mathrm{R}-\mathrm{O}-\mathrm{CH}_{3}+\mathrm{NaCl}$

By means of a reaction between the cobalt complex $\mathrm{K}-\mathrm{Co}(\mathrm{CO})_{4}$ and sodium methylate the ether may also be formed. Using sodium hydroxide or an amine instead of sodium methylate, it is possible to form phenyl acetic acid or an amide. Dynamit Nobel A.G. [5-8] carbonylated benzyl chloride at $55^{\circ} \mathrm{C}$ and a $\mathrm{CO}$ partial pressure of 0.4 0.6 MPa. In our case we wanted to get data on the influence of temperature and CO partial pressures on the carbonylation yield and selectivity in order to obtain information on the suitability of the low pressure carbonylation for the manufacture of fine chemicals.

\section{Literature survey}

A great number of carbonylation reactions are described in the literature; most of them are carried out at high temperatures and under high $C O$ partial pressures and relate to the carbonylation of olefines $[1,10-13]$. The carbonylation of halides at relatively low temperatures and pressures is a more recent development, as can be concluded from the work of Falbe on reactions with CO $[14,15]$. In 1970 he mentions [14] the following process conditions for the carbonylation of halides: temperatures of $200-300{ }^{\circ} \mathrm{C}$, CO partial pressures of 60-100 MPa and nickel carbonyl as catalyst. As a new development with $\mathrm{NaCo}(\mathrm{CO})_{4}$ as a catalyst he discusses a single case with process conditions of $0-100{ }^{\circ} \mathrm{C}$ and atmospheric pressure giving a product yield of $80 \%$ for the carbonylation of mainly alkyl halides [16]. Ten years later in 1980, however, Falbe [15] discusses three examples of carbonylations under mild conditions, all using $\mathrm{Co}_{2}(\mathrm{CO})_{8}$ as a catalyst, all three being patents of Dynamit Nobel A.G. [6,7]. El-Chahawi and Prange [9] give two examples of the carbonylation of benzyl chloride with $\mathrm{Co}_{2}(\mathrm{CO})_{8}$ catalysts: a phenyl acetic methyl ester yield of $95 \%$ can be reached [5-8] according to the patents of Dynamit Nobel A.G.

Apart from cobalt carbonyl other catalysts can also be used, for example $\mathrm{Fe}(\mathrm{CO})_{5}[17], \mathrm{Na}_{2} \mathrm{Fe}(\mathrm{CO})_{4}[18]$, $\operatorname{Pd}\left[\left(\mathrm{C}_{5} \mathrm{H}_{6}\right)_{3} \mathrm{P}\right]_{2} \mathrm{Cl}_{2}[19]$ and thodium catalysts.

It follows [5-8] that there are three possible ways (methods) to carry out carbonylation of chlorides, all having one aspect in common: by keeping the concentration of one (or both) reactant(s) low, side reactions can be suppressed to a great extent. These possibilities are:

(1) the reaction mixture consisting of a solution of sodium methylate in methanol and containing the catalyst - the chloride to be carbonylated (if necessary dissolved in methanol) is slowly added to the reaction mixture;

(2) the reaction mixture consisting of a mixture of chloride, methanol and catalyst-a sodium methylate solution is slowly added to the reaction mixture;

(3) the reaction mixture consisting of a solution of catalyst in methanol-a sodium methylate solution in methanol and the chloride are both added slowly and separately to the reaction mixture.
All three possible methods are applied to carbonylate aromatic chlorides [5-8]. Using methods (2) and (3) benzyl chloride can be converted into phenyl acetic methyl ester with a high yield. Method (1), slow addition of benzyl chloride, is used by Sawicki [20] and carried out at $0{ }^{\circ} \mathrm{C}$ and a $\mathrm{CO}$ partial pressure of $0.1 \mathrm{MPa}$. The phenyl acetic methyl ester yield is just $5 \%$; the main product is found to be methyl benzyl ether. On mixing the sodium methylate with alumina, the phenyl acetic methyl ester yield increases to $20 \%$. The product yield can be increased to $70 \%$ by using an activated sodium methylate/alumina base.

All the experiments mentioned are carried out in a homogeneous liquid phase. It is also possible to carry out the reaction in a heterogeneous liquid system [21] consisting of an organic phase containing the catalyst and a water phase. The water phase is used to extract the desired product out of the organic reaction phase. In this way the product concentration in the reaction phase can be kept low and the main product now is not an ester but an acid. The conversion of these reactions is relatively low and $60 \%$ at maximum.

\section{Experimental set-up and technique}

All the experiments were carried out in the experimental installation described in Fig. 1. The heart of the installation is the autoclave: the volume of this steel reactor is $845 \mathrm{ml}$. The temperature is measured in the liquid. The $\mathrm{CO}$ pressure can be kept constant to within $0.02 \mathrm{MPa}$. Gas and liquid are mixed by a magnetically operated pulsating stirrer. The reactant to be added is injected with a precision piston pump (Geveke type Lewa HL2). The flow can be measured with a calibrated glass burette. The reactant to be injected is stored under a nitrogen atmosphere. The carbon monoxide buffer has a volume of $1024 \mathrm{ml}$; the pressure and temperature are recorded. The reactor is heated with an external handcontrolled electrical heater or cooled by blowing air around the vessel. Because the benzyl chloride is corrosive $[22,23]$, the reaction was carried out in a glass vessel inserted in the autoclave; the inserted vessel has a volume of around $500 \mathrm{ml}$ and can be filled with a maximum of $250 \mathrm{ml}$ of liquid. This made temperature control very difficult, consequently temperature rises of $15-30{ }^{\circ} \mathrm{C}$ could occur during an experiment. Therefore all experimental temperatures given in this study are averages. The adiabatic temperature rise for the average reactant concentration used was calculated to be $150-160^{\circ} \mathrm{C}$. Using a minimum of methanol, pure benzyl chloride and a $30 \mathrm{wt} . \%$ sodium methylate solution in methanol, the adiabatic temperature rise even increases to $270-$ $280{ }^{\circ} \mathrm{C}$. The reactant supply during an experiment is kept constant by controlling the flow and is expressed as moles reactant added per mole of the other reactant in the reaction mixture per second. During a series of experiments only one of the process parameters such as the CO partial pressure, the average reactor temperature, the reactant addition rate or the pulsation rate was varied at a time. The experiments were carried out either according to method 1, the slow addition of benzyl 


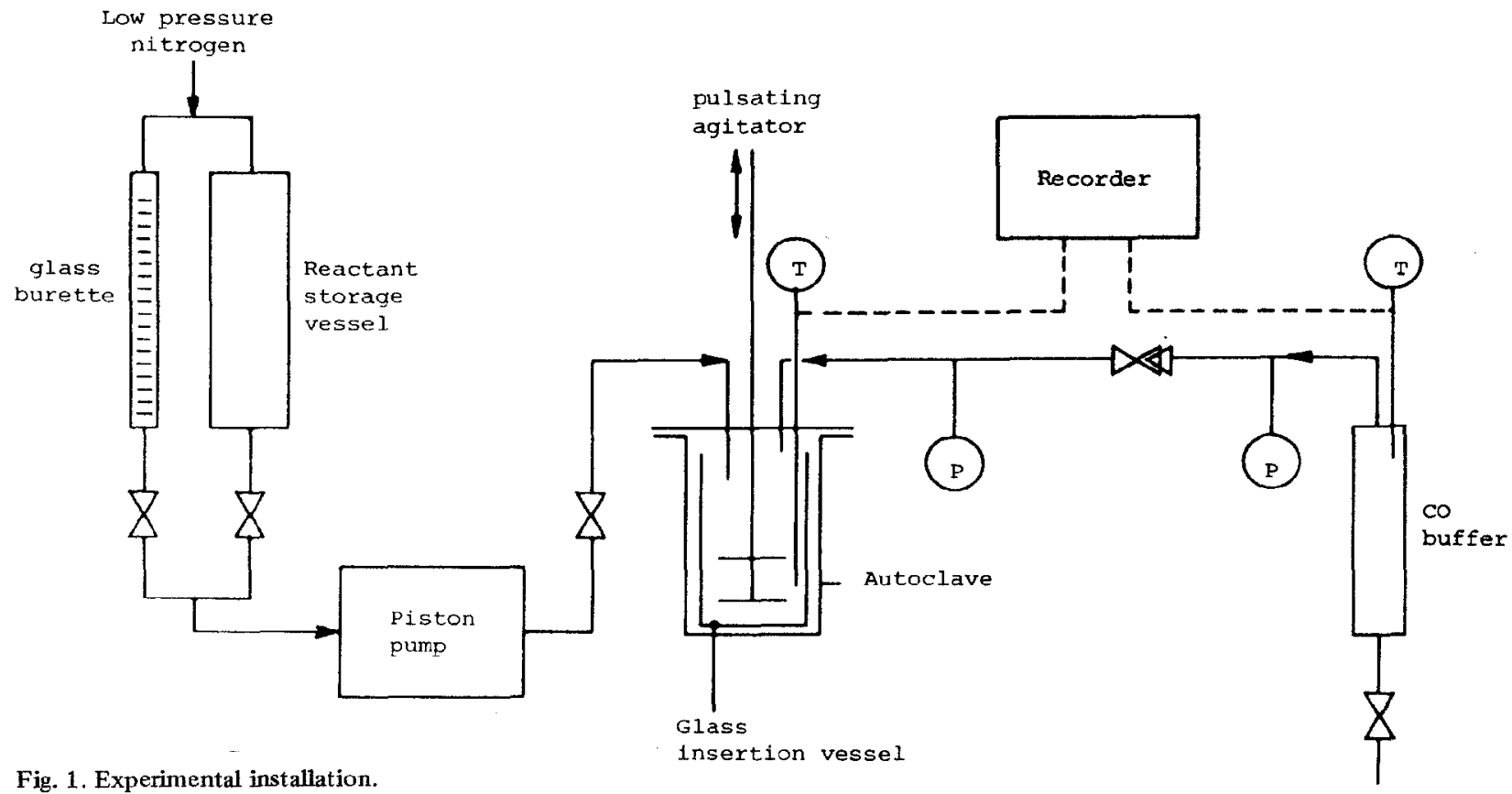

chloride, or method 2, the slow addition of sodium methylate. From the pressure decrease and temperature change of the $\mathrm{CO}$ storage vessel the amount of $\mathrm{CO}$ consumed is calculated. The $\mathrm{CO}$ consumption rate is a direct measure of the reaction rate.

\section{Description of a typical experiment}

$40 \mathrm{~g}(1.25 \mathrm{~mol})$ methanol, $54.4 \mathrm{~g}(0.43 \mathrm{~mol})$ benzyl chloride and $1.9 \mathrm{~g}(5.6 \mathrm{mmol})$ dicobalt octacarbonyl with a total volume of about $100 \mathrm{ml}$ were placed in the reaction vessel; the solution to be added during the run consisted of $96.3 \mathrm{~g}(3.0 \mathrm{~mol})$ methanol and $24.4 \mathrm{~g}(0.45$ mol) sodium methylate with a total volume of about $135 \mathrm{ml}$. All chemicals were reagent grade from Merck. After closing the reactor, rinsing with $\mathrm{CO}$ and pressurizing the reactor, and if necessary heating up the reaction mixture, the reactor conditions were kept constant for half an hour in order to reach steady state conditions. Then the second reactant was slowly added at the desired flow rate. The reaction is considered to be terminated when the pressure decrease in the CO storage vessel is less then $0.02 \mathrm{MPa}$ in 15 minutes. Then the reactor was depressurized and rinsed with nitrogen. The reactor contents were analysed with a gas chromatograph. A Varian 6000 with a thermal conductance detector was used, together with a Hewlett Packard integrator (type HP 3392 A), or a Varian 3400 with a Mame ionizalion detector. In both gas chromatographs a $2 \mathrm{~m} \times 1 / 4$ in. glass column packed with $5 \%$ FFAP on chromosorb W-HP (80/100 mesh) was used.

With the composition data obtained the conversion and selectivity were calculated according to:

$$
\begin{aligned}
\text { Conversion in } \%= & 100-\frac{\begin{array}{l}
100 \times \text { mol } \% \text { benzyl chloride } \\
\text { at end of reaction }
\end{array}}{100-\text { mol } \% \text { methanol }} \\
& \begin{aligned}
100(\mathrm{~mol} \% \text { phenyl acetic methyl ester } \\
+ \text { mol } \% \text { benzyl methyl ether })
\end{aligned}
\end{aligned}
$$

Selectivity in $\%=\frac{100 \times \text { mol } \% \text { phenyl acetic methyl ester }}{(100-\text { mol\% methanol }) \times \text { conversion }}$

All other experiments were executed in a similar way.

\section{Experimental results and their discussion}

The results of the experiments are given in Table 1 and Figs. 2-5. Figures $2-4$ show the influence of the different process variables on the conversion (lower part of the Figures) and the selectivity (upper part) of the carbonylation of benzyl chloride to phenyl acetic methyl ester. For slow addition of benzyl chloride there is almost no influence of the CO partial pressure on the conversion of benzyl chloride (Fig. 2(a)), whereas the selectivity increases with increasing $\mathrm{CO}$ partial pressure. At high CO partial pressure the formation of phenyl acetic methyl ester is favoured over the formation of benzyl methyl ether. The conversion is strongly influenced by the average reactor temperature (Fig. 2(b)). At low temperatures the conversion is low because of too low reaction rates. High reaction temperatures prohahly cause a deactivation of the catalyst. When the 
TABLE 1. Experimental results

\begin{tabular}{llllll}
\hline Temper- & CO & Reactant & Mixing & Conver- & Selec- \\
ature & pressure & flow & intensity & $\begin{array}{l}\text { sion } \\
\text { tivity }\end{array}$ \\
$\left({ }^{(} \mathrm{C}\right)$ & $(\mathrm{MPa})$ & $\left(10^{-3} \mathrm{~mol}\right.$ & $\begin{array}{l}\text { (pulses } \\
(\%)\end{array}$ & $(\%)$ \\
& & $\left.\mathrm{mol}^{-1} \mathrm{~s}^{-1}\right)$ & $\left.\mathrm{s}^{-1}\right)$ & & \\
\hline
\end{tabular}

\begin{tabular}{|c|c|c|c|c|c|}
\hline \multicolumn{6}{|c|}{ Slow addition of benzyl chloride } \\
\hline 33 & 0.72 & 0.147 & 0.53 & 90 & 80 \\
\hline 33 & 0.44 & 0.147 & 0.53 & 92 & 84 \\
\hline 33 & 0.23 & 0.147 & 0.53 & 88 & 77 \\
\hline 33 & 0.94 & 0.147 & 0.53 & 90 & 84 \\
\hline 5 & 0.72 & 0.147 & 0.53 & 57 & 69 \\
\hline 44 & 0.73 & 0.147 & 0.53 & 90 & 83 \\
\hline 30 & 1.15 & 0.147 & 0.53 & 88 & 90 \\
\hline
\end{tabular}

Slow addition of sodium methylate

\begin{tabular}{rrrrrr}
36 & 0.71 & 0.162 & 0.53 & 98 & 100 \\
36 & 0.54 & 0.162 & 0.53 & 98 & 99 \\
36 & 0.41 & 0.162 & 0.53 & 98 & 100 \\
36 & 0.21 & 0.162 & 0.53 & 94 & 96 \\
36 & 0.85 & 0.162 & 0.53 & 98 & 100 \\
36 & 1.03 & 0.162 & 0.53 & 94 & 99 \\
22 & 0.72 & 0.162 & 0.53 & 91 & 99 \\
8 & 0.72 & 0.162 & 0.53 & 70 & 93 \\
45 & 0.72 & 0.162 & 0.53 & 97 & 99 \\
36 & 0.72 & 0.162 & 0.53 & 95 & 99 \\
40 & 0.73 & 0.195 & 0.53 & 96 & 99 \\
40 & 0.73 & 0.233 & 0.53 & 96 & 99 \\
40 & 0.73 & 0.287 & 0.53 & 97 & 99 \\
40 & 0.73 & 0.365 & 0.53 & 94 & 98 \\
40 & 0.73 & 0.460 & 0.53 & 93 & 97 \\
40 & 0.73 & 0.730 & 0.53 & 90 & 92 \\
40 & 0.73 & 0.625 & 0.53 & 91 & 94 \\
36 & 0.73 & 0.460 & 0.38 & 90 & 94 \\
36 & 0.73 & 0.460 & 0.63 & 94 & 98 \\
36 & 0.73 & 0.460 & 0.82 & 95 & 98 \\
36 & 0.73 & 0.460 & 1.13 & 95 & 98 \\
36 & 0.73 & 0.460 & 1.47 & 93 & 97 \\
\hline
\end{tabular}

CO partial pressure is low the dicobalt octacarbonyl is unstable at high temperatures. At low conversion the benzyl chloride concentration is relatively high: this causes an incrcasc in the non-catalysed formation of benzyl methyl ether, resulting in a decrease in selectivity.

When the sodium methylate is added slowly to the reaction mixture the $\mathrm{CO}$ partial pressure has a strong influence on the conversion (Fig. 3(a)). The conversion
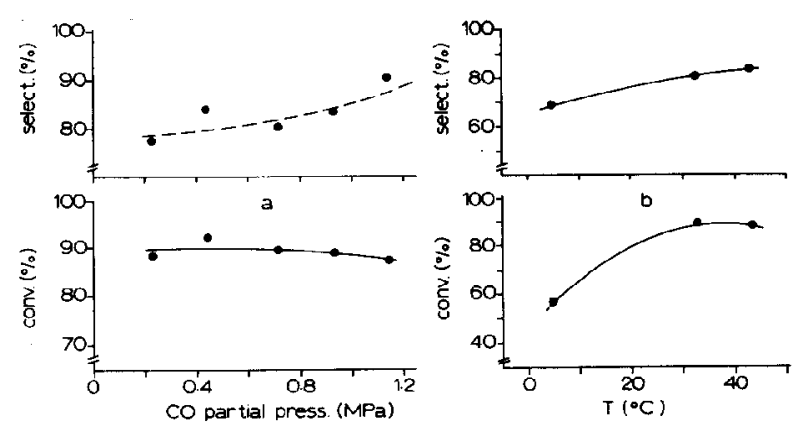

Fig. 2. Slow addition of benzyl chloride: the influence of (a) the CO partial pressure $\left(33^{\circ} \mathrm{C}, 0.147 \times 10^{-3} \mathrm{~mol} \mathrm{~mol}^{-1} \mathrm{~s}^{-1}, 0.53\right.$ pulses $\mathrm{s}^{-1}$ ); (b) the average reactor temperature $(0.72 \mathrm{MPa} \mathrm{CO}$, $0.147 \times 10^{-3} \mathrm{~mol} \mathrm{~mol}^{-1} \mathrm{~s}^{-1}, 0.53$ pulses $\mathrm{s}^{-1}$ ).
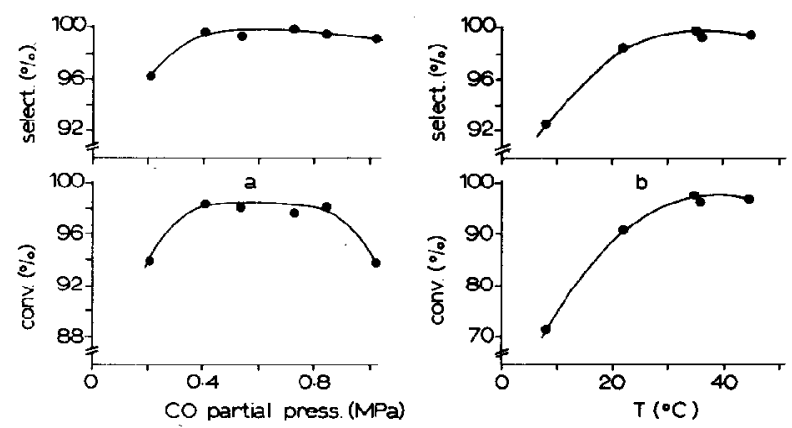

Fig. 3. Slow addition of sodium methylate: the influence of (a) the $\mathrm{CO}$ partial pressure $\left(36^{\circ} \mathrm{C}, 0.162 \times 10^{-3} \mathrm{~mol} \mathrm{~mol}^{-1} \mathrm{~s}^{-1}\right.$, 0.53 pulses $\left.\mathrm{s}^{-1}\right)$; (b) the average reactor temperature $(0.72 \mathrm{MPa}$ $\mathrm{CO}, 0.162 \times 10^{-3} \mathrm{~mol} \mathrm{~mol}^{-1} \mathrm{~s}^{-1}, 0.53$ pulses $\mathrm{s}^{-1}$ ).
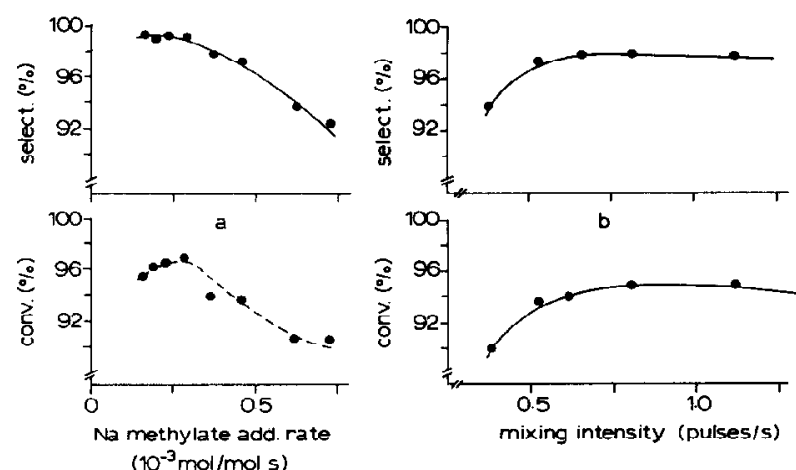

Fig. 4. Slow addition of sodium methylate: the influence of (a) the addition rate of the sodium methylate $\left(40^{\circ} \mathrm{C}, 0.73 \mathrm{MPa} \mathrm{CO}\right.$ 0.53 pulses $\left.\mathrm{s}^{-1}\right)$; (b) the mixing intensity $\left(36^{\circ} \mathrm{C}, 0.73 \mathrm{MPa} \mathrm{CO}\right.$, $\left.0.460 \times 10^{-3} \mathrm{~mol} \mathrm{~mol}^{-1} \mathrm{~s}^{-1}\right)$.



Fig. 5. CO consumption rate vs. sodium methylate addition rate $\left(40{ }^{\circ} \mathrm{C}, 0.73 \mathrm{MPa} \mathrm{CO}, 0.53\right.$ pulses $\left.\mathrm{s}^{-1}\right)$.

sharply decreases when the $\mathrm{CO}$ partial pressure becomes lower than 0.4 MPa: apparently the $\mathrm{CO}$ shortage decreases the reaction rate and increases the catalyst deactivation. The decrease of the reaction rate is accompanied by a rise in the sodium methylate concentration which in turn brings about a decline in selectivity.

The conversion also decreases at $\mathrm{CO}$ partial pressures higher than $0.85 \mathrm{MPa}$. Two possible explanations are as follows.

(1) An intermediate step in the reaction is the equilibrium

$\mathrm{R}-\mathrm{Cl}+\mathrm{Co}(\mathrm{CO})_{4}{ }^{-} \rightleftharpoons \mathrm{R}-\mathrm{Co}(\mathrm{CO})_{3}+\mathrm{CO}+\mathrm{Cl}^{-}$ 
At high $\mathrm{CO}$ partial pressures this equilibrium moves to the left, causing a decrease in reaction rate.

(2) The following equilibrium occurs:<smiles></smiles>

\section{Cobalt complex $\mathrm{R}-\mathrm{C}-\stackrel{\mathrm{O}}{\mathrm{Co}(\mathrm{CO})_{4} \text {, formed at high } \mathrm{CO}}$} partial pressures, does not react with sodium methylate, so that a part of the catalyst becomes inactive.

We are unable to make a choice between these two explanations. It is known that cobalt carbonyls can lose a ligand $[24,25] ; \mathrm{HCo}(\mathrm{CO})_{3}$ can be formed from $\mathrm{HCo}(\mathrm{CO})_{4}$. This points to explanation (1). In the literature there is no evidence supporting the second explanation which is based on the hydroformylation reactions, where a similar complex like $\mathrm{R}-(\mathrm{CO})-\mathrm{Co}(\mathrm{CO})_{4}$ is not split by hydrogen. In the carbonylation reactions the splitting is not effectuated by the lightly active hydrogen but by the very reactive sodium methylate. It is questionable whether $\mathrm{R}-(\mathrm{CO})-\mathrm{Co}(\mathrm{CO})_{4}$ is stable enough to resist an attack by sodium methylate. Probably the first explanation is correct. The fact that conversion and selectivity decrease at pressures beyond $0.8 \mathrm{MPa}$ does not have to be in contradiction with the knowledge that industrial carbonylation processes are operated at 60 $100 \mathrm{MPa}$. Industrial processes are not only operated at high $\mathrm{CO}$ pressures but also at high temperatures $\left(200-300{ }^{\circ} \mathrm{C}\right)$. The optimum pressure interval will shift to higher pressures as the temperature increases; a high CO pressure is needed to stabilize cobalt carbonyl at high temperatures. The effect of temperature on conversion and selectivity of the carbonylation process for slow addition of the sodium methylate (Fig. 3(b)) is about the same as that for slow addition of benzyl chloride. At a constant $\mathrm{CO}$ partial pressure there is an optimum in temperature where the conversion and selectivity are maximum. The exact location of this maximum is probably determined by the $\mathrm{CO}$ partial pressure. The deactivation rate of the catalyst at high temperatures can be decreased by raising the $\mathrm{CO}$ partial pressure.

Conversion and selectivity are also influenced by the addition rates of sodium methylate (Fig. 4(a)). At low addition rates the loss in conversion is caused by a slow but steady deactivation of the catalyst owing to intrinsic decomposition. The sodium methylate concentration is always very low, therefore the selectivity is high. At high sodium methylate addition rates the conversion decrement is caused by an increasing sodium methylate concentration which deactivates the catalyst and/or a limited rate for the $\mathrm{CO}$ transport from the gas phase to the liquid phase. Both these effects, a high sodium methylate concentration and a limited $\mathrm{CO}$ transport rate, cause an increase in catalyst deactivation and therefore a decrease in conversion. Because of an increasing sodium methylate concentration the reaction rate of the non-catalysed benzyl methyl ether formation is increased, so that the selectivity decreases. A third possibility is that the reaction rate is the limiting factor; in that case a high sodium methylate concentration causes the decrease in catalyst activity.

The CO consumption rate, for slow addition of sodium methylate, is constant during the addition of the first $80 \%$ of the sodium methylate: in Fig. 5 the $\mathrm{CO}$ consumption rate is plotted against the sodium methylate addition rate. Both the $\mathrm{CO}$ consumption rate and the sodium methylate addition rate are expressed in mol per mol benzyl chloride in the reaction mixture per second. The $\mathrm{CO}$ consumption rate is almost equal to the sodium methylate addition rate up to an addition rate of $0.360 \times$ $10^{-3} \mathrm{~mol} \mathrm{~mol}^{-1} \mathrm{~s}^{-1}$. At higher addition rates the $\mathrm{CO}$ consumption rate is limited by the $\mathrm{CO}$ transport from the gas to the liquid phase or by the reaction rate: less $\mathrm{CO}$ is consumed by reaction than can be consumed, according to the amount of sodium methylate added. At addition rates between $0.280 \times 10^{-3} \mathrm{~mol} \mathrm{~mol}^{-1} \mathrm{~s}^{-1}$ where the conversion reaches its maximum (see Fig.4(a)) and $0.360 \times 10^{-3} \mathrm{~mol} \mathrm{~mol}^{-1} \mathrm{~s}^{-1}$ the $\mathrm{CO}$ transport rate or the reaction rate starts to become limiting, so that the liquid phase is no longer saturated with $\mathrm{CO}$. The results given in Fig. 4(b) demonstrate that the $\mathrm{CO}$ transport from the gas to the liquid phase becomes the controlling factor at low mixing intensities. This can be seen fion the deciease in conversion and selectivity at low mixing intensities where the mass transport rates between the gas and the liquid phase are low.

\section{Significance and conclusions}

Both methods used, the slow additions of either benzyl chloride or sodium methylate, can be compared with respect to the conversion and selectivity. Slow addition of benzyl chloride gives a maximum conversion of $92 \%$ or a maximum selectivity of $90 \%$ in our experimental set-up: these maxima cannot be reached simultaneously. With slow addition of sodium methylate a maximum conversion of $98 \%$ and a maximum selectivity of $100 \%$ can be reached at the same time. For an industrial application of the low pressure carbonylation process therefore the slow addition of sodium methylate is the best method, because almost no by-product is formed (selectivity $100 \%$ ) and the amount of benzyl chloride that has to be recycled is minimal (conversion $98 \%$ ).

It is also possible to compare the two methods on the basis of reaction rates. The consumption rate of $\mathrm{CO}$ as plotted in Fig. 6 is a direct measure of the reaction rate. Figure 6(a) shows that the $\mathrm{CO}$ consumption rate, and therefore the reaction rate, for a slow addition of benzyl chloride is not constant during the first part of the reaction. This implies that the reaction rate is not only controlled by the addition rate of the reactant but also by another unknown variable.

For slow addition of sodium methylate (Fig. 6(b)) the reaction rate is constant until a benzyl chloride concentration of $0.2-0.4 \mathrm{~mol}^{-1}$ is reached; after that the reaction rate starts to decrease. In the first part of the reaction at low addition rates the reaction rate is determined by the rate of supply of the sodium methylate. 

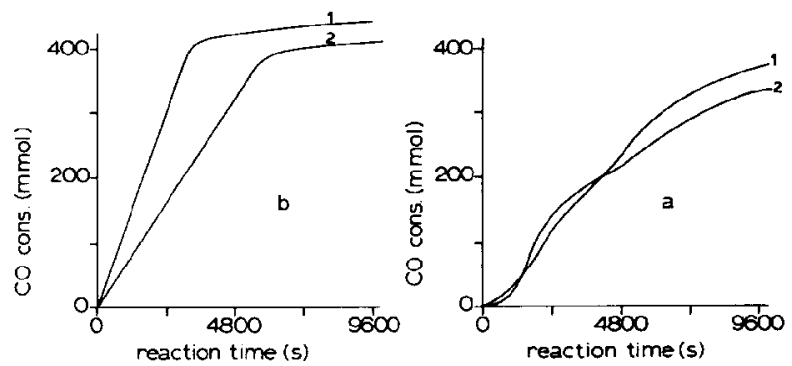

Fig. 6. CO consumption vs. the reaction time: (a) slow addition of benzyl chloride $\left(0.53\right.$ pulses $\mathrm{s}^{-1}, 33^{\circ} \mathrm{C}, 0.147 \times 10^{-3} \mathrm{~mol}$ $\mathrm{mol}^{-1} \mathrm{~s}^{-1}$; curve $1,0.94 \mathrm{MPa}$ CO; curve 2, $1.15 \mathrm{MPa} \mathrm{CO}$ ); (b) slow addition of sodium methylate $\left(0.53\right.$ pulses $\mathrm{s}^{-1}$; curve 1 , $40{ }^{\circ} \mathrm{C}, 0.73 \mathrm{MPa} \mathrm{CO}, 0.287 \times 10^{-3} \mathrm{~mol} \mathrm{~mol}^{-1} \mathrm{~s}^{-1}$; curve 2 , $36{ }^{\circ} \mathrm{C}, 0.54 \mathrm{MPa} \mathrm{CO}, 0.162 \times 10^{-3} \mathrm{~mol} \mathrm{~mol}^{-1} \mathrm{~s}^{-1}$ ).

Comparison of the initial conditions shows that methods 1 and 2 differ strongly in the concentration of sodium methylate or benzyl chloride in the reaction mixture. We have no cxplanation of how the sodium methylate concentration influences the reaction. High sodium methylate concentrations not only occur for slow addition of benzyl chloride but also when sodium methylate is added with relative high addition rates.

Sawicki [20] slowly added benzyl chloride to the reaction mixture at $0{ }^{\circ} \mathrm{C}$ and at atmospheric $\mathrm{CO}$ pressure and obtained a product yield of $5 \%$. We obtained a product yield of $39 \%$ (conversion $57 \%$, selectivity $69 \%$ ) at $5{ }^{\circ} \mathrm{C}$ and at $0.72 \mathrm{MPa} \mathrm{CO}$ and a product yield of $68 \%$ at $33{ }^{\circ} \mathrm{C}$ and $0.23 \mathrm{MPa} \mathrm{CO}$. Taking the difference in reaction conditions into account the results of Sawicki and ours are comparable. We can also compare our results with the experiments of Dynamit Nobel A. G. under slightly different conditions: these were performed at $55{ }^{\circ} \mathrm{C}$ and a $\mathrm{CO}$ partial pressure of $0.4-0.6 \mathrm{MPa}$ and a product yield of $98 \%$ was obtained. We obtained a product yield of $93 \%-98 \%$ at process conditions of 30-40 ${ }^{\circ} \mathrm{C}$ and $0.4-0.8 \mathrm{MPa} \mathrm{CO}$ partial pressure. Our results therefore agree with those found by Dynamit Nobel A. G.

The results of our work can be summarized in the following conclusions.

(1) Carbonylation of benzyl chloride with high phenyl acetic methyl ester yields can be done under mild reaction conditions.
(2) To suppress undesirable side reactions one of the key reactants has to be added slowly to the reaction mixture.

(3) Slow addition of sodium methylate results in the highest conversions and selectivities.

(4) The conversion is maximal at an optimal CO pressure: too low pressures cause a $\mathrm{CO}$ shortage which decreases the reaction rate and increases the catalyst deactivation; too high $\mathrm{CO}$ pressures probably also cause a catalyst deactivation.

\section{References}

1 W. Reppe, Liebigs Ann. Chem., 582 (1953) 1.

2 G. Luft and M. Schrod, J. Mol. Catal., 20 (1983) 185.

3 M. Schrod and G. Luft, J. Mol. Catal., 22 (1983) 169.

4 M. Schrod and G. Luft, Ind. Eng. Chem., Prod. Res. Dev., 20 (1981) 649 .

5 Dynamit Nobel A. G., Patent NL 7311 369, 1973.

6 Dynamit Nobel A. G., Patent NL 7502 744, 1975.

7 Dynamit Nobel A. G., Patent NL 7511 504,1975.

8 Dynamit Nobel A. G., Patent NL 7613 343, 1976.

9 M. El-Chahawi and U. Prange, Chem.-Ztg., 102 (1978) 1.

10 R. F. Heck, J. Am. Chem. Soc., 90 (1968) 5518.

11 R. F. Heck, J, Am. Chem. Soc., 85 (1963) 2013.

12 M. Nakayama and T. Mizorohi, Bull. Chem. Soc. Jpn., 43 (1970) 569.

13 M. Nakayama and T. Mizorohi, Bull. Chem. Soc. Jpn., 42 (1969) 1124

14 J. Falbe, Carbon Monoxide in Organic Synthesis, Springer Verlag, Berlin, 1970.

15 J. Falbe, New Synthesis with Carbon Monoxide, Springer Verlag, Berlin, 1980.

16 R. F. Heck and D. S. Breslow, J. Am. Chem. Soc., 85 (1963) 2779.

17 G. C. Tustin and R. T. Hembre, J. Org. Chem., 49 (1984) 1761.

18 J. P. Collmann, S. R. Winter and R. G. Komoto, J. $A m$. Chem. Soc., 95 (1973) 249.

19 A. Schoenberg, I. Bartoletti and R. F. Heck, J. Org. Chem., 39 (1974) 3318.

20 R. A. Sawicki, J. Org. Chem., 48 (1983) 5382.

21 F. Francalanci, J. Organomet. Chem, 232 (1982) 59.

22 National Association of Corrosion Engineers, Corrosion Data Survey, NACE, Houston, Sth edn., 1974.

23 F. Rabalt, Corrosion Guide, sec. rev. edition, Elsevier, Amsterdam, 2nd rev. edn., 1968.

24 N. v Kutepow, W. Himmele and H. Hohenschutz, Chem.-Ing.Tech., 37 (1965) 383.

25 G. Natta, R. Excoli, S. Castellano and F. H. Barbini, J. Am. Chem. Soc., 76 (1954) 4049. 